\author{
Abstracta Iranica \\ Abstracta Iranica Revue bibliographique pour le domaine irano-aryen \\ Volume 32-33 | 2013 \\ Comptes rendus des publications de 2009-2010
}

\title{
Yosef Garfinkel, Saar Ganor (eds.). Khirbet Qeiyafa, vol. 1. Excavation Report 2007-2008
}

\section{Astrid Nunn}

\section{(2) OpenEdition}

1 Journals

\section{Édition électronique}

URL : http://journals.openedition.org/abstractairanica/40267

DOI : 10.4000/abstractairanica.40267

ISSN : 1961-960X

Éditeur :

CNRS (UMR 7528 Mondes iraniens et indiens), Éditions de l'IFRI

\section{Édition imprimée}

Date de publication : 1 décembre 2013

ISSN : 0240-8910

\section{Référence électronique}

Astrid Nunn, "Yosef Garfinkel, Saar Ganor (eds.). Khirbet Qeiyafa, vol. 1. Excavation Report 2007-2008 », Abstracta Iranica [En ligne], Volume 32-33| 2013, document 70, mis en ligne le 01 juillet 2016, consulté le 05 octobre 2020. URL : http://journals.openedition.org/abstractairanica/40267 ; DOI : https:// doi.org/10.4000/abstractairanica.40267

Ce document a été généré automatiquement le 5 octobre 2020.

Tous droits réservés 


\title{
Yosef Garfinkel, Saar Ganor (eds.). Khirbet Qeiyafa, vol. 1. Excavation Report 2007-2008
}

\author{
Astrid Nunn
}

\section{RÉFÉRENCE}

Yosef Garfinkel, Saar Ganor (eds.). Khirbet Qeiyafa, vol. 1. Excavation Report 2007-2008.

Jerusalem, 2009, 304 p.

1 Khirbet Qeiyafa, situé à $20 \mathrm{~km}$ au nord de Lachish, est l'objet de fouille depuis 2007. Il s'agit d'une fortification massive dont la période la plus importante est le $\mathrm{X}^{\mathrm{e}} \mathrm{s}$. av. J.-C. Bien que les couches plus récentes soient bien représentées, et qu'un certain nombre d'objets datent de la période entre la fin de l'Age du Fer (Stratum IV) et le début de l'époque hellénistique (Stratum III), la céramique est qualifée de "Late Persian-Early Hellenistic" (p. 209 sq.). Qu'il s'agisse de mortaria, de cratères, de céramique de cuisine ou de jarres, tous ces types sont bien achéménides. Ce nouveau site s'ajoute à la liste déjà longue des sites achéménides dans cette région: Tell es-Safi, Beth Shemesh, Azekah, Lachish, etc.

\section{AUTEURS}

ASTRID NUNN

Université de Munich 